Прегледни чланак

Mladen N. Brkić, Ph.D. Student

University of Novi Sad

Faculty of Law Novi Sad

mladen19922@gmail.com

\title{
ACTUAL (DE FACTO) EXPROPRIATION ON THE AREA OF THE CITY OF NOVI SAD
}

\begin{abstract}
In addition to the public interest established by the Government of the Republic of Serbia, the authorized user of immovable property may initiate a procedure for the forcible deprivation of immovable property while providing compensation corresponding to the market value of the confiscated real estate. Although the Expropriation Law precisely stipulates the conditions and procedure for the implementation of expropriation, the question arises as to whether it is possible to act differently, that is, whether expropriation is considered only a procedure that meets all the statutory requirements (existence of public interest, proposals of an authorized user, expropriation decision and compensation for expropriated immovable property) or it may be possible to expropriate, but only by its very nature. Sometimes state bodies or public enterprises undertake certain actions that have the same effect as expropriation, which courts call actual expropriation, although this concept does not exist in the regulations of the legal system of the Republic of Serbia
\end{abstract}

Keywords: expropriation, actual expropriation, actual expropriation in the Futog area, actual expropriation in the Veternik area.

\section{INTRODUCTION}

If there is a law regulating a particular matter, that law should regulate all the situations that it may have in relation to that matter. This means that if we have the Expropriation Law, which regulates the matter of expropriation, it should be applied to an indefinite number of cases that may arise. Any treatment that does not respect the legal rules would mean that such treatment is illegal and that certain procedures should be initiated with the aim of protecting the rights of the persons to whom the rights have been established. There were certain situations 
when there was an expropriation of real estate in the Republic of Serbia, and that the procedure was not followed by the law, and previous owners did not receive compensation for the seized immovable property. In those situations certain authorities took the actions which have the same effect as expropriation, so-called actual expropriation. This behavior represents a grave violation of the basic constitutionally guaranteed rights, and therefore the Constitutional Court played a significant role in resolving a problem called "actual expropriation". Although it could be said that the Constitutional Court has solved cases in favor of the applicants of constitutional appeals, Miloš Prica has a very critical attitude towards the actions of the Constitutional Court, considering that the Constitutional Court legalizes the factual arbitrariness of state bodies by the institute of actual expropriation. ${ }^{2}$

Actual expropriation in the territory of the City of Novi Sad, ie, Futoga area and Veternik area, shows us the inconsistency of the state authorities in lawful treatment. Although the timeframe of actual expropriation does not coincide with Veternik and Futog (in Veternik, the actual expropriation was carried out in XXI century, while in Futog, in the seventies of the twentieth century), the question arises as to whether it is possible that, although regulations existed at the time of actual expropriation, do anything contrary to the laws governing this field.

\section{ACTUAL (DE FACTO) EXPROPRIATION IN THE AREA OF NOVI SAD}

Expropriation means a forced proceeding for the transfer of ownership of a real estate from one legal subject to another, or its restriction, with the existence of a public interest and the granting of a compensation for a seized property which cannot be lower than the market value of the immovable property. ${ }^{3}$ It is regulated

${ }^{1}$ There is not a small number of Constitutional Court (further CC) decisions on actual expropriation in which the $\mathrm{CC}$ found a violation of the right to property (Article 58 of the Constitution of the Republic of Serbia "Official Gazette RS" No. 98/2006) for a fair trial (Article 32 para. 1 of the Constitution) and equal protection of rights (Article 36, paragraph 1 of the Constitution). In the continuation of the article, there will be more to say about some CC decisions. Not only does the Constitutional Court play a very important role, but the European Court of Human Rights in Strasbourg has made very important decisions regarding actual expropriation (see decisions in cases: Papamichalopulos and others v. Greece (https://hudoc.echr.coe.int/eng\#\{“itemid":[“001-57836"]\}); Carbonara and Ventura v. Italy (https://files.pca-cpa.org/bi-c/1.\%20Investors/4.\%20Legal\%20Authorities/CA299.pdf); Sporrong and Lonnorth v. Sweden (http://web.changenet.sk/aa/files/207e345aa907113543b0857cd685 6c71/a52_1982_eu_sud_case_of_sporrong_and_lonnorth_vs_sweden.pdf)). Read more: Dragoljub Popović, European humān rights $\bar{l}$ law (Evropsko pravo ljudskih prava),Official gazette, 2012.

${ }^{2}$ Miloš Prica, Expropriation as a legal institute (Eksproprijacija kao pravni institute), Doctoral dissertation, Niš, 2016., pg. 318.

${ }^{3}$ Expropriation can be viewed in a wider sense and in the narrow sense. By expropriation in broader terms, we consider the entire expropriation process, from determining the public interest, 
by the Expropriation $\mathrm{Law}^{4}$ which explicitly and precisely prescribes the conditions and procedure for the deprivation of the property right on real estate. The question arises as to whether it is possible to do expropriation otherwise, or whether it is possible to expropriate the immovable property, without any of the procedures related to expropriation being initiated. ${ }^{5}$ If there is a law regulating a particular matter, it should apply to an indeterminate number of situations to which the law applies. Although this was generally accepted, there were certain situations in which expropriation of immovable property occurred, without any procedure concerning expropriation being initiated, nor any compensation for the seized immovable property was given to the previous owners. This is about taking action by state authorities that have the same effect as expropriation (actual expropriation). ${ }^{6}$ It is precisely in these situations that the role of the courts is enormous because they have established through their practice certain rules to be followed later ${ }^{7}$ (judicial practice is not formally a source of law in the legal system of the Republic of Serbia, but the practice of the Constitutional Court is generally binding).

From the upcoming sections we will see what problems the court in Novi Sad has encountered, and the cases of actual expropriation that will be said to, have happened in the territory of the local communities of Futog and Veternik.

\subsection{Actual expropriation in the Futog area}

In the period from 1974 to 1976, in the area of Futog, there was land consolidation, which ultimately had effect only as an expropriation, with no expropriation

through the adoption of a decision on expropriation, to the determination of a compensation corresponding to the market price of the expropriated real estate. Unlike this, the narrow sense only refers to the procedure for the adoption of the expropriation decision, because only this decision is the legal basis for the transfer of the ownership right or its restriction.

4 The Expropriation Act of 1995, "Official gazette RS "br. 53/95, "Official gazette SRJ “no. 16/2001 - decision of CC and "Official gazette"no. 20/2009, 55/2013 - decision CC and $106 / 2016$ - authentic interpretation.

${ }^{5}$ It refers to the procedure for: determining the public interest, making a decision on expropriation and determining compensation.

${ }^{6}$ Indirect expropriation should be distinguished from a actual expropriation. If, by the action of a single act or action, the owner is brought into the state of the so-called. bare property, it is about the actual expropriation.. Otherwise, if the restriction of private property leads the titular into the state of imposing a specific victim, it is indirect expropriation (M. Prica, op.cit., pg. 106)

7 Taking into account the "history" of the practice of the courts, we could state that, initially, the courts were not sufficiently addressed in the problem of actual expropriation and their decisions were constituted a violation of the constitutionally guaranteed rights. This applies not only to the courts of lower instance, but in certain decisions the appeal courts, as well as the Supreme Court of Cassation, have violated the constitution guaranteed rights. In the continuation of the article we will mention examples of several violations of the constitution guaranteed rights by the highest courts in the Republic of Serbia. 
procedure being initiated. The Commission for Land consolidation of the Municipality of Novi Sad (hereinafter: the Commission) for the Cadaster Municipality of Futog, in the procedure of the survey of the construction zone, made a land consolidation for the Cadaster Municipality of Futog (hereinafter: K.O. Futog), only establishing the factual situation in the construction area. Each parcel was measured as it was enclosed, i.e. the factual condition was determined regardless of how the parcel looks in the plan. After the survey, all the parcels had a different surface due to the system of measures and due to the precision of the measurement. In this process, many parcels were cut off with new measures, by introducing newly designed roads and streets to new dimensions, so some gardens were divided because new streets were opened. From the Municipality of Novi Sad, the Commission was instructed that some new parcels would be publicly property, i.e. owned by the Municipality of Novi Sad. Although the Commission for Land Consolidation was concerned, the Commission did not conduct any land grouping, nor did change parcels as it should have done in the procedures for land consolidation. The Commission noted that some parts of the garden or the yard of individual owners and residential buildings in Futog were designed as future streets in Futog, as well as what are the land areas that need to be transferred onto the street according to plan. What is controversial, in this procedure of land consolidation (expropriation), was that the Commission did not have the power to determine any compensation, in cash or in land parcels, to the landowners in the construction area who have land ownership. Members of the Commission have just instructed citizens about compensation in a future expropriation process, which was never initiated.

According to the valid Law on land consolidation and arondation ${ }^{8}$ at the time of the land consolidation, the consolidation of agricultural land is carried out in order to enable the economic treatment of agricultural land and create more favorable conditions for the development of an agricultural settlement, by creating larger and more correctly land parcels. According to Article 5 of the same law, if simultaneously with the procedure of land consolidation there is a need for construction of roads, canals and other structures, whose construction is not directly connected with the land consolidation, the land for their construction is given out of the land mass with fair compensation under condition of determining a general interest in the manner prescribed by law. From the front of the exhibited it can be concluded that the land consolidation was not done for the purpose of grouping land in order to create larger and more correctly land parcels for processing agricultural land. In this case, it was about construction land (whose purpose has not yet been changed) and the need for constructing a street. There were not even done a grouping of land for rational use, so that land for the construction of the street is allocated from this land consolidation mass. In addition, perhaps most importantly, previous owners have not been identified and paid compensation for seized land.

8 "Official gazette of Socialist Autonomous Province of Vojvodina" no. 27/72 
Also, it is not clear why actual expropriation was carried out through the Commission because at that time there were regulations that regulated expropriation. ${ }^{9}$

Such a legally unsolved situation lasted for a very long time. Over 35 years, previous owners were left without any compensation for seized land. Only since 2011 the proceedings against the City of Novi Sad, as a legal successor of the Municipality of Novi Sad, have been initiated for actual expropriation, that is, for the purpose of obtaining compensation corresponding to the market value of the seized land.

It is justifiable to ask which rules to apply and what to do with this situation.

The problem is that the process of land consolidation is only partially implemented. The procedure was supposed to be carried out by the Commission for land consolidation, which, after compiling the record and informing the participants that their parcels were changed into new streets with new survey, was obliged to make a decision on the land consolidation according to which the parcels with new parcel numbers would be transferred from private property participants in public ownership. In order to clarify this situation in the judgment of the Basic Court in Novi Sad, it was stated: "Having in mind that the participants in the land consolidation for the seized parcels did not receive any other land in the form of compensation, the Commission was obliged to establish a fair compensation for the seized parcels according to the expropriation regulations. As the Commission has never made such a decision, this means that the land consolidation procedure has not been completed, and the participants have the right to seek compensation which should have been established in the case". ${ }^{10}$ The situation is compounded by the fact that the Commission for land consolidation, which was responsible for adopting appropriate solutions, no longer exists and there are no conditions for the consolidation procedure to end in the same Commission. The former owner remains: "As a participant in the consolidation, he can only realize his rights in the litigation procedure, i.e., to request that the Municipality of Novi Sad for K.O. Futog, whose body was obliged to complete the procedure of land consolidation, make a decision on land consolidation and determine the compensation for the expropriated land, i.e. the legal successor of the City of Novi Sad shall pay compensation for the seized land ".11

Existing Expropriation Law in Art. 72, paragraph 1, in its final provisions, states that the procedure on the proposal for expropriation which has not been legally concluded by the date of entry into force of this Law shall be terminated according to the regulations that were in force until the date of entry into force of this Law, except in cases when the expropriation procedure has not been finalized,

${ }^{9}$ In that period, the Expropriation Act of 1968 ("Official gazette of Socialist Federal Republic of Yugoslavia”, no. 11/68 and 30/68) was in force.

${ }^{10}$ Decision of the Basic Court in Novi Sad no. P 8018/2013 from 11/12/2013.

${ }^{11}$ Ibidem. 
and it is about business and residential buildings. From this article we can conclude that we should apply the regulations that were valid at the time when the actions were taken because the procedure for land consolidation, i.e. for expropriation has not been completed or no solution has been made, but here we have the situation that expropriation was still carried out, although a formal expropriation decision has not been formally made. The immovable property of a private person has been seized and the same real estate has been registered as a public domain in public records. Actual expropriation was carried out, but without any compensation. Having this in mind, paragraph 2 of Article 72 of the Law states: "The procedure for determining the compensation for expropriated real estate, in which, until the date of entry into force of this law, no agreement on compensation has been concluded, i.e. no final court decision has been made, it shall end according to the provisions of this Law". From this it can be concluded that in this situation the valid Expropriation Law should be applied.

Therefore, the City of Novi Sad, as the legal successor of the Municipality of Novi Sad for K.O. Futog is obliged to pay the amount of compensation according to the Expropriation Law in force, where this compensation should be equal to the market value of the expropriated real estate.

Since we have determined which law is being applied, we have come to the next problem, which is the way of determining the market value of expropriated real estate.

\subsubsection{Determination of compensation}

The compensation for expropriated immovable property, i.e. for seized agricultural or construction land, is determined in money, unless otherwise provided by the Expropriation Law. ${ }^{12}$ The amount of compensation in money is determined according to the market value ${ }^{13} 14$ of the real estate that is determined either at the moment of concluding the agreement or according to the circumstances at the moment of the adoption of the first instance decision on compensation. ${ }^{15}$ This

${ }^{12}$ Article 42, paragraph 1 Expropriation Law

${ }^{13}$ When it comes to expropriation related to foreign investments, there are numerous methods of calculating compensation for expropriation (see P. Đundić, Methods for Calculation of Compensation for Expropriation of a Foreign Investment(Metodi za izračunavanje naknade za izvršenu eksproprijaciju stranog ulaganja), Zbornik radova Pravnog fakulteta u Novom Sadu, no. 4/2015, pg. 1845-1860)

${ }^{14}$ When it comes to foreign investments, there is an understanding that a distinction should be made between legal and illegal expropriation in terms of the amount of compensation (see P. Đundić, The Consequences of the Distinction between Lawful and Unlawful Expropriation of Foreign Investment (Posledice razlikovanja zakonite I nezakonite eksproprijacije stranog ulaganja), Zbornik radova Pravnog fakulteta u Novom Sadu, no. 3, t.2 /2011, pg. 599-612.

${ }^{15}$ Article 41, paragraph 2 Expropriation Law 
provision is repeated especially when it comes to determining the compensation for agricultural and construction land. In order to avoid asking who assesses market value, the legislator stated in Article 42, paragraph 2 of the Law on Expropriation that the assessment of market value is carried out by the authority competent for determining the tax on the transfer of absolute rights to immovable property. ${ }^{16}$

The state authority which is responsible for determining the tax for the transfer of absolute real estate rights to Novi Sad is Tax Administration, which means that it is competent to determine the estimation of market price. Although it is precisely regulated who assesses the market value, in practice, the assessment of the Tax Administration is only the basis for the determination of the compensation. Very often the assessment of the market value of the Tax Administration does not correspond to the actual state of the market value. Such a situation leads to prosecutors hiring court experts to determine the value of expropriated real estate. ${ }^{17}$ The statement that the assessment of the Tax Administration represents only the basis for the determination of compensation is observed in the decision of the Constitutional Court Už-5686/2011 dated 28.02.2018. Namely, the courts initially considered that the Tax Administration, taking into account only Article 42 of the Law on Expropriation, is solely responsible for determining the compensation for the expropriation. Thus, the High Court in Pirot ${ }^{18}$ partially reversed the decision of the Basic Court of Pirot - Judicial Unit in Bela Palanka R. 40/11 in the section on costs, while in the remaining part, the solution is confirmed. In the reasoning of the above-mentioned decision, the High Court states that: “... the first instance court correctly decides when the compensation for the seized land was determined based on the assessment given by the competent tax authority; that by the provision of Article 42 paragraph 2 of the Expropriation Law explicitly stipulates that the assessment of market value is carried out by the authority competent for determining the tax on the transfer of absolute rights to immovable property and that the possibility of determination and estimation of compensation in some other way is forbidden". Contrary to this paragraph, the Constitutional Court considers that the provisions of the Law on Expropriation do not deprive the possibility that

${ }^{16}$ Above mentioned authority carries out only an estimation of market value but does not determine the amount of compensation for expropriated real estate, which means that such an assessment is not binding on the determination of the compensation. We will explain this in more details below.

${ }^{17}$ By expertizing, every court procedure raises not only the amount that is determined as a wage and reward for court experts, but also, as a rule, special hearings for the defense of expertize, which means additional costs that the losing party must compensate. So, instead of a proper assessment of the Tax Administration, we have a situation that the City of Novi Sad will surely pay the real amount of market value, increased for the costs of civil proceedings.

${ }^{18} \mathrm{Gž} \mathrm{442/11} \mathrm{dated} \mathrm{06.10.2011.} \mathrm{This} \mathrm{decision} \mathrm{was} \mathrm{brought} \mathrm{to} \mathrm{trial} \mathrm{at} \mathrm{the} \mathrm{Constitutional} \mathrm{Court,}$ which made a decision ordering above mentioned High Court to repeat the proceedings (Už $-5686 / 2011$ of 28 February 2013). 
the compensation and market price of expropriated real estate is determined and estimated in another way. ${ }^{19}$ Namely: "... the task of the Tax Administration is not to determine the market price of an expropriated immovable property but to carry out its assessment, where, in the event that a compensation agreement is not reached, only the court is competent to determine the compensation for expropriated immovable property in a non-contentious procedure". The Constitutional Court specifically emphasizes that from the provision of Article 136 para. 2 of the Law on Non-Contentious Proceedings states that, in addition to the assessment given by the Tax Administration, the court may also take other evidence proposed by the participants and determine the expertise, if it assesses that they are of significance for determining the amount of compensation "20.

When a court expert assesses the value, he should consider the assessment of the authority responsible for determining the tax on the transfer of absolute rights to immovable property, assessment of tax administration. If a court expert

${ }^{19}$ In essentially similar matters, the Appeal Court in Niš made the decision no. 102/11 of 21.06.2011. in which he stated that the market price of expropriated real estate is determined solely on the basis of an assessment by the Tax Administration. This decision was the subject of a constitutional request and the Constitutional Court in decision no. Už - 3824/2011 from 03.04.2013. annulled the judgment of the Appeal Court for the same reasons stated in decision Už - 5686/2011.

${ }^{20} \mathrm{Už}-5686 / 2011$ dated 28.02.2013. In the aforementioned decision, the Constitutional Court goes one step further, considering that the assessment of the Tax Administration is "the lowest amount of compensation for expropriated immovable property that the court can determine." This attitude can cause certain problems. Namely, the Tax Administration performs an estimation of the market value of immovable property on the basis of the parameters defined in Article 4 of the Rulebook on the method of determining the base of property tax on real property rights ("Official gazette of the Republic of Serbia", No. 38/01, 45/04 and 27/11 ). Such an assessment is not binding and is permitted in accordance with Article 136 para. 2 of the Law on Non-Contentious proceedings ("Official gazette Socialistic Republic of Serbia", No. 25/85 and 48/88 and "Official gazette of the Republic of Serbia”, No. 46/95 - other law, 18/2005 - 2012, 45/2013 - other law, 55/2014, 6/2015 and 106/2015 other law), the court will also make other evidence suggested by the participants if it finds that they are relevant for the determination of compensation, and, if necessary, an expert report. Determining the expertise does not mean that it is prejudicial to the adoption of the evaluation of the expert. The expert examination is only evidence in the procedure that the court judges evaluate in accordance with a free judge's opinion. Under the "force" of the arguments, the court will adopt an assessment of the Tax Administration, and not the assessment of expert. Taking above mentioned into account, there could be three situations. First, the Tax Administration estimates the value lower than the expert assessed, but the court adopts the evaluation of the expert. Second, the assessment of tax administration is lower than the assessment established by the expert report, but that court, under the "force of" arguments, adopts an assessment of the tax administration. Thirdly, the assessment of tax administration is higher than the assessment established by the expert, but the court considers that the assessment established by the expert is relevant. If a third situation occurs, the court would be in trouble because, according to the Constitutional Court, the assessment of tax administration would be "the lowest amount of compensation that the court can determine", and court will have to adopt an assessment of the Tax Administration, although expert assessment is correct, which can certainly be unfair. 
did not take this into consideration, such a evaluation could not benefit as evidence in the proceedings. ${ }^{21}$

Here another justification is raised, which is how to determine the market value of the land if, at the time of execution of the expropriation, by type, it was a construction parcel and by the way of use it was field, and after expropriation the conversion was made. This is because the construction land for which no conversion was made is cheaper than the one for which it was executed. The solution to this problem is given by the legislator in Article 41, paragraph 2 of the Law on Expropriation, in which among other things, states that the amount of compensation in money is determined at the market price according to the circumstances at the moment of the adoption of the first instance decision on compensation. Having above mentioned in mind the market value is determined at the time of the decision, irrespective of whether a conversion has been made in the meantime. This was also decided in the judgment of the High Court no. Gž 3663/2013 from 21.05.2014. in which it is stated that The Complainant's allegations of the defendant, which point out that it is completely contrary to the principle of equivalence of benefits because the land taken at the time of seizure, by type, is construction land, and by the way of using the field, are not affected by the lawfulness and regularity of the contested decision because the compensation for the seized land is determined according to the status and condition of the land that it has at the time of determining the compensation, not at the time of confiscation.

\subsubsection{Objection of obsolescence}

Examining the judgments of the Basic and Higher Court, the objection of obsolescence is the legal remedy most frequently used during the first instance proceedings, as well as in the appeal allegations. In each proceeding, the defendant stated that the claim was obsolescence because it was a matter of an obligation claim or a claim for compensation of damages, whereby this request expire within 3 years from the knowledge of the damage and to the person who caused the damage (subjective period) while with the expiration of a period of 5 years (objective time) from the date when the damage was caused claim is outdated, irrespective of whether the injured party found out about the damage and for the person who caused the damage. Having in mind that the actual expropriation was carried out in the seventies, according to the defendant, all the claims related to that period were out of date. The problem with this is that the compensation for expropriated real estate is not treated as a damage suffered by the previous owner, so the subjective period of 3 years or an objective time limit of 5 years cannot be applied. This because the Expropriation Law is a lex specialis in relation to the Law on Obligations,

\footnotetext{
${ }^{21}$ See section about actual expropriation in Veternik area.
} 
and since the Law on Expropriation does not provide for obsolescence in the payment of compensation based on expropriation, in conflict with the provisions of several laws, the provisions of the special law will apply, which is, in this case Law on Expropriation. This was reflected in many judgments, both the Basic and the High Court. Thus, the High Court in its decision no. 3663/2013 states: "As the subject matter is regulated by the Expropriation Law, this law excludes the application of the Law on Obligations as lex specialis, which is why are allegations groundless that the court erroneously rejected the objection of the obsolete claim on the subject compensation, as this is not a matter of claim compensation for damage to the regulated Low on Obligations (deadlines for obsolescence 3 and 5 years after the occurrence of a harmful event), but about claiming compensation for expropriated land. Since the Expropriation Law does not prescribe limitation periods for claims for expropriation, the objection of obsolescence is not established". A more detailed explanation why the right to compensation for expropriated immovable property is not outdated is stated in the decision of the Supreme Court of Serbia No. Gzz 101/96 dated 08.12.1997. Namely...the procedure for the determination of compensation is initiated by the court and conducted ex officio (Article 134 paragraph 1 Low on Non-Contentious proceedings), and not on the proposal of the former owner of the expropriated real estate ... the former owner of an expropriated real estate does not make any omission with non-compliance with the request for the establishment of a fair compensation, but it is a failure of the authority that administers this procedure ex officio. Consequently, the right to compensation for expropriated immovable property does not become obsolete because in this case this claim has not yet been established, and the obsolescence of compensation could not begin to run.

\subsection{Actual expropriation in the Veternik area}

The expropriation that took place on the territory of the local community Veternik had a different background compared to Futog. War events on the territory of Croatia and Bosnia and Herzegovina caused migration of the population and for a short period the number of inhabitants of Veternik was nearly doubled. ${ }^{22}$ Such a situation has imposed a need to buy land to build houses. The problem with the land in Veternik was that the landowners had large land plots that were not divided on smaller land plots to be tempting to buy. Having in mind that immigrants did not have enough money to buy large plots of land, the owners have come up with an idea that themselves carry out the parceling of their parcels, in order to be tempting for immigrants. The parceling was carried out in a way that each plot has an optimal number of square meters in order to meet the needs of

22 According to official data, the number of inhabitants in Veternik until 1991 was about 10,000 , and by 2002 it increased to over 18,000 . 
future owners. Such shredding of land resulted in the creation of enclaves (parcels that would not have a direct exit to any traffic). According to the existing urban plans, the construction of the streets should have passed through certain, previously planned routes. The planned streets did not suit individual landowners because it would mean that certain plots would not be attractive enough to buy. For example, according to plan, the distance between the streets is 150 meters which would mean that the plots between each should have 75 meters of length. Such proportions would not correspond to citizens who had come from war zones and who did not have much money. For this reason, the owner would divide the parcels into three sections, each 50 meters long, with it that one, central plot will be enclave. As a solution to the situation, the owners have come to realize that between the first and second plot, or the second and third plot, build the street, beyond any city decisions. They realized that if they did not do that, they would not be able to sell the central parcel. The owners thus sold plots telling the future owners of the enclaves that their plots had an exit to the road (which was initially just a basic earthy road) and that later the street would be built. So we got the situation that there are projected streets, and besides there are factual streets (earthy roads) that were built out of any planning document. In such situation, on the original earthy roads later, streets were built, with works being carried out by some of the public companies responsible for building the streets. Laboring are carried out without any decision on the expropriation of the competent authority and with that, the land is practically taken away from the former owners and turned into a publicly owned street, where no compensation has been given for the seized land.

At expropriating in Veternik, several questions are raised. First of all, who has legitimacy, i.e., who is the holder of rights and obligations in material relations.

Real legitimacy should have an earlier owner of an expropriated land. Who is former owner in this situation is not clear. Land sales took place in the nineties, and the construction of streets has begun at the beginning of XIX century. The aforementioned suggests that buyers of this land should be really legitimized because they were the owners of the plot at the time of the expropriation, but what if the previous owner remained the owner of that plot that was left for the street and on which the street was later built. The first question of all that needs to be solved is whether the former owner, along with the parcel, sold to each new owner part of the road, i.e. whether the part relating to the future street also included in the purchase price. If it was accounted for in the purchase price and part of the road, real legitimacy in the procedure for compensation would have buyers of that land. This position is represented in a decision of the Supreme Court of Cassation, Rev. 1808/2010 stating: "The former owner shall not be entitled to a compensation for land that has been left as a road during the sale of the land, and subsequently actually taken to the street without his consent, if the value of the contested land is included in the price of each individual sold parcel, regardless of the fact that it is not specifically 
stated"23. If, by any chance, the former owner sold only those plots, without counting the road, real legitimacy will have former owner, i.e., in this relationship, the seller because he left for himself the plot on which the street should be built. ${ }^{24}$

Determination of ownership of real estate at the time of execution of expropriation is done on the basis of a contract of sale and a contract of division. Since the former owner had made a parceling of a land, there were no special markings for each plot, but each buyer purchased a certain co-ownership share in relation to the square meters he had purchased. According to the purchase agreement, the buyer acquires the co-ownership share. Since the sales contract is insufficient, we need a contract on the division of parcels, which was concluded by the seller with all customers, i.e., to the co-owners, through with the authorized institution can perform the parceling. Authorized institution, i.e. The Republic Geodetic Authority performs the division based on the contract of division for each co-owner, if there are conditions, and determines ownership on each new parcel that gets a new number. With the help of this division, it is possible to determine if the road includes some of the parcel owned by the buyer or the road represents a new parcel owned by the seller or in the co-ownership of the seller with the buyer (buyers). Depending on that, it can be answered who has real legitimacy.

\subsubsection{Case study}

A part about expropriation (actual) in Veternik will be determined in the study of a very interesting case that shows the diversity of life situations that have many legal connotations.

As stated in the previous section, in the nineties many landowners in Veternik performed factual parceling of real estate. According to the established factual situation in the case P 2237/14, in 1994 the prosecutor made a parceling of immovable property by dividing it into several parcels, one of which he retained for himself, and the others sold to ten customers. The agreement about diversion concluded in 2008 found that all buyers and prosecutors are co-owners on parcel no. 1727 of total area of $8495 \mathrm{~m} 2$, each in certain parts. Also, it was noted that after the implementation of the parceling, which was carried out by Republic Geodetic Authority, The Real Estate Cadaster, new parcels were created (1727/1, 1727/2, $1727 / 3,1727 / 4,1727 / 5,1727 / 6$ and 1727/7), some of which were solely owned by one person, while others were co-owned. Plot number 1727/4 is entered in the real estate evidence as a field of 2 class with area of $1907 \mathrm{~m}^{2}$, and as a type of land is

${ }^{23}$ Decision of The Supreme Court of Cassation, Rev. 1808/2010 of 16.11.2011.

${ }^{24}$ In a substantially similar legal case, The Constitutional Court made a decision. In Decision no. Už-5533/2011 from 03.07.2014., has been annulled the decision of The Supreme Court of Cassation Rev. 2385/10 of 29.06.2011. The Constitutional Court stated that explicit or tacit consent for the use of a land for passage is not considered to be a sale of goods or rights. 
marked land in the construction area. A total of 11 persons were registered on this plot as the co-owner. The prosecutor had the largest co-ownership share (1352/1907) on plot number 1727/4. According to the Regulatory Plan of the settlement of Veternik ${ }^{25}$ plot number 1727/4 is located in the area "public area -street" as the purpose of the land is indicated "public area-street", where the plot is not intended for construction, so that neither regulative nor building line ${ }^{26}$ were specified and represents part of Stevan Peci Popovic Street in Veternik. The Republic Geodetic Authority, The Real Estate Cadaster Office, issued a certificate in 2012 confirming that cadastral plot number 1727/4 Cadaster Municipality of Veternik belongs to the part of Stevan Peci Popovic Street, whereby with the decision on naming the streets in Veternik, the name of Nova 21 street was replaced by the name Stevan Peci Popovic Street. For a long period of time, the prosecutor did not visit his plot, and when he did, he noticed that on his plot there was an asphalted street with lights and that on both sides of the street were facilities with gas, electricity, telephone and other necessary infrastructure. He concluded that the parcel in question is the street so that it is no longer suitable for agricultural production, although it is still labeled as "field of 2 class" in public registers, while the real estate is still privately owned, i.e. in the total of 11 persons. Considering that the expropriation was carried out, although the expropriation procedure was never carried out for the plot in question nor the decision regarding the expropriation was made, in 2013, the prosecutor initiated a proceeding against the City of Novi Sad for compensation for actual expropriation.

During the procedure, in 2013, the City Council of the City of Novi Sad issued a decision on determining the average price per square meter of the respective real estate by zones in the territory of the City of Novi Sad for determining the property tax for 2014 according to which the average price per square meter for the area of "Veternik" amounts to 30.862,00 dinars for construction land and 30,00 dinars for agricultural land. Taking into account this decision, the court expert made an evaluation and determined what the market value of the real estate would be.

The big problem was due to the fact that no works related to the construction of this street were recorded in any public company. Thus, the City Administration for Traffic and Roads did not issue a building permit for the parcel 1727/4, i.e., for the construction of a street. Also, the City Construction Institute did not conduct investment works at the opening of Stevan Peci Popovic Street in Veternik, as well as the public company "Waterworks and Sewerage", whereby water supply network was built in the mentioned street and it was registered by public company

25 "Official gazette of The City of Novi Sad "no. 3/2001, 3/2003 and 17/2003.

${ }^{26}$ According to Article 2, paragraph 1, item 9-10 of the Law on Planning and Construction, the regulation line is a line that separates the surface of certain public purposes from the areas intended for other public and other purposes, while the construction line is a line at, above and below the surface of the earth and the water to which the construction of the building's basis is allowed. 
"Waterworks and Sewerage" as illegal with the status of temporarily registered consumers. Apart from the lack of written evidence, the witness, co-owner of the real estate and the exclusive owner of the parcel 1727/2, does not know who ordered the execution of works, nor who financed the execution of works, but only assumes that the works were financed by the City of Novi Sad. In addition, the Prosecutor does not provide evidence that the City of Novi Sad participated in the execution of works or in the financing of works.

The result of the above is that the street was built and that it is a part of Stevan Peci Popovic Street, but that street is privately owned, or co-owned by 11 persons. Such a plot is no longer suitable for agricultural production, although in public books it is still labeled as "2nd class field". The expropriation procedure has never been conducted, nor the decision on land seizure has been made, nor the compensation, and on the basis of this, no amount of money has been paid to the prosecutor. Although it has not been established, in the court proceedings, that one of the public companies participated in the construction of a street, in the opinion of the court, the circumstance that the same maybe engaged on asphalting is not sufficient to establish that one of the companies had an order to carry out the works as well that order was issued by the City of Novi Sad. From such a situation, the court could not determine that the City of Novi Sad performed an actual expropriation and refused a claim. Also, the court considers that the amount of the lawsuit has not been proven, since the court expert did not take into account the assessment of the Tax Administration during the expert examination (it was not even suggested this evidence, i.e, it was not requested from the Tax Administration to submit an assessment of the market value).

On this decision the prosecutor appealed to the Appeal Court in Novi Sad, which in its decision no. Gž 3359/14 from 18.11.2014. rejected the appeal and fully accepted the reasons set forth in the first instance decision concerning the failure of the defendant to take factual and legal action in order to establish the authority in the contested plot and that the prosecutor failed to provide evidence to the court about the circumstance of the market price of the concrete parcel, in accordance with Article 42 paragraph 2 of the Law on Expropriation. Also, the Court of Appeal has pointed out that the prosecutor from his unlawful behavior, which is reflected in the illegal self-initiative parceling of land and the formation of the access road, can not demand from defended an obligation to compensate him for the market value of his co-ownership share of the plot (street) while simultaneously transferring the right of ownership on that part of the immovable property in favor of the defended.

Considering that with this decision has been violate his constitutional right to a fair trial under Article 32 para. 1 of the Constitution of the Republic of Serbia ${ }^{27}$,

${ }^{27}$ In Article 32 para. 1 of the Constitution states that: "Everyone has the right that, independent, impartial and legally established court, fairly and in within a reasonable time, publicly discuss and 
the prosecutor filed a constitutional complaint, which the Constitutional Court, in its decision no. Už-206/2015 dated 22.06.2017. accepted. Regarding the position on the lawfulness of the assessment of market value, the Constitutional Court did not specify in precise terms. The Constitutional Court just recall the Decision Už-5686/2011 stating that the assessment of the Tax Administration represents the lowest amount of compensation that the court can determine but that, in addition to the assessment given by the Tax Administration, in accordance with Article 136 para. 2 of the Law on Non-Contentious proceedings, it is permissible to carry out other evidence proposed by the participants, as well as an expert evaluation, but does not indicate anything about lack of estimation of Tax Administration in expert opinion. Taking into account the specificity of the situation, we consider that the expert was obliged to take into account the Tax Administration's assessment, because Article 42, paragraph 2 of the Expropriation Law obliges him, and we consider that the first instance court and the Court of Appeal correctly decided that the amount of the claim was not proven.

Regarding the decision on whether the actual expropriation was carried out, the Constitutional Court explained in detail why he overturned the decision of the Appeal Court in this part. Namely, regardless of the fact that the contested parcel in the public records of the real estate is still kept as a field and as its co-owners are registered by the applicant and other persons, everyone has the right to use this parcel as a street in a way that is in order to achieve this purpose prescribed by law and by-laws, otherwise, if the applicant with other persons who are still in the public records are registered as co-owners, could determine the manner and extent of its use ... The very fact that the Regulatory Plan of the Veternik area ... controversial cadastral parcel determined for the street indicates the inadmissibility / arbitrariness of the court's finding of "the absence of the existence of relevant public legal acts". Also, in respect of the essentially identical factual and legal situation in the Decision no. Už-472/2014 dated 25.02.2018. stated that ... when the land is designated by the planning act of the local government unit as a local road, the second or third order, or the street, from that moment, the land becomes an asset in the public domain ... Therefore, the local government unit is obliged that land, that has become a public property, expropriate from the previous owner, i.e., to exclude him from the possession of the previous user, and to pay the appropriate compensation for this.

Taking into account the above, we consider that the actual expropriation has been carried out and that the claim has been justified, but the Constitutional Court's view that the land from the moment when the plan is designated for the local road becomes a public property asset must be limited to the situation when

decide on his rights and obligations, the basis of the suspicion that was the reason for the initiation of the proceedings, as well as the charges against him ". 
actual expropriation is made (when actions or acts that have the same effect as expropriation are undertaken) because otherwise this could have many legal repercussions. For example, if a particular land is with planning document designated for the local road, and if no formal or actual expropriation was made, the position of the Constitutional Court that parcel is a matter of a public property could be limitation for the owner of property in the enjoyment of property rights, which is certainly not acceptable.

\section{CONCLUSION}

Actual expropriation could not exist because there are precise rules for the implementation of expropriation. Not in a single regulation is mentioned, but it exists and it is the creation of court practices. Although there are precise rules for the implementation of expropriation, we have noted that the diversity of life events can impose a number of issues for which there are no clear rules of conduct. In such circumstances, the courts has enormous role in trying to solve the existing problem in a fair manner. But the problem that is not immediately noticed is that, if there is a planning act that encompasses a certain immovable property, the state authority can "choose" whether, for example, the construction of a street will move a formal expropriation procedure or will opt for actual expropriation, which has the same effect as if it was a formal expropriation. Such treatment is nothing more than a factual arbitrariness of the authorities, i.e., of its employees. Taking into account the above, until the strict liability of state authorities is carried out, the role of the courts will remain to "cure" the violation of the constitutional protected fundamental rights. 


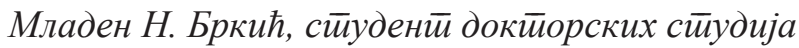

Универзийей у Новом Саду

Правни Факулитети у Новом Саду

mladen19922@gmail.com

\section{Фактичка експропријација на подручју града Новог Сада}

Сажеейак: Уз йосӣојање јавног̄ инӣереса, који уйврђује Влада Рейубли-

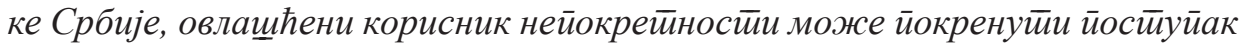

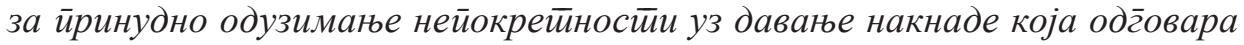

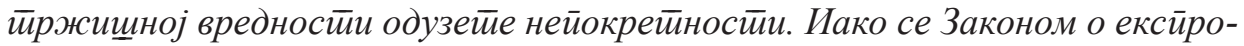

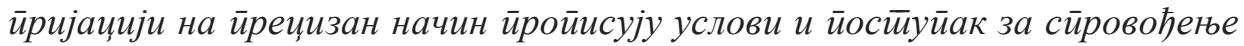

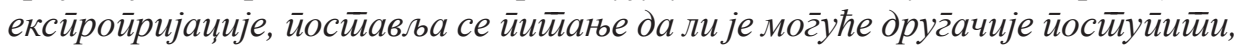

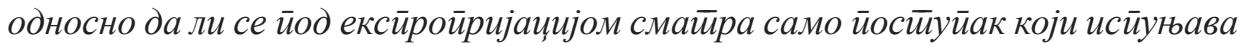

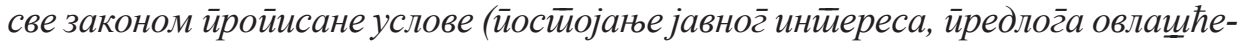
ног̄ корисника, рещень о ексирроиријацији и накнаде за ексйройрисану нейо-

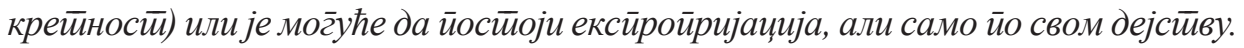
Понекад државни органи односно јавна ӥредузећа йредузимају одређене радюе које имају истио дејстиво као ексирройријација, а које судови називају фак-

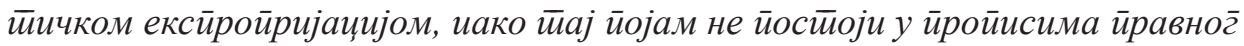
сисӣема Рейублике Србије.

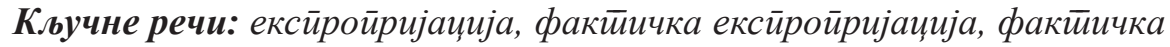

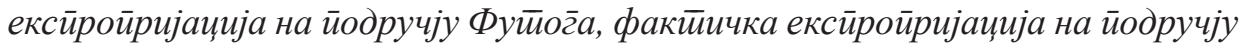
Вейерника.

Датум пријема рада: 08.12.2017. 